Dagmara Borkowska', Elżbieta Radzikowska², Jolanta Załęska², Jerzy Ziołkowski ${ }^{3}$, Magdalena Klatt' Zofia Zwolska', Ewa Augustynowicz-Kopeć', Kazimierz Roszkowski-Śliż²

'Zakład Mikrobiologii, Instytut Gruźlicy i Chorób Płuc w Warszawie

Kierownik: prof. dr hab. n. med. E. Augustynowicz-Kopeć

${ }^{2}$ III Klinika Chorób Płuc Instytutu Gruźlicy i Chorób Płuc w Warszawie

Kierownik: prof. dr hab. n. med. K. Roszkowski-Śliż

${ }^{3}$ Klinika Pneumonologii i Alergologii Wieku Dziecięcego; I Katedra Pediatrii Warszawskiego Uniwersytetu Medycznego

Kierownik: prof. dr hab. n. med. M. Kulus

\title{
Testy IGRA w diagnostyce zakazienia prątkami gruźlicy w wybranych sytuacjach klinicznych
}

\section{Interferon-Gamma Release Assays in the diagnosis of latent tuberculosis infection in clinical situations}

Praca była finansowana z działalności statutowej Instytutu Gruźlicy i Chorób Płuc

\section{Abstract}

Until recently, the basic test to identify latent tuberculosis infection (LTBI) was the tuberculin skin test, despite its limitations in the form of low sensitivity and specificity. Currently, Interferon Gamma Release Assays from peripheral blood are used for a rapid diagnosis of LTBI and measurement of the interferon gamma (IFN- $\gamma$ ) levels secreted by specific T cells stimulated with Mycobacterium tuberculosis antigens. Detection of LTBI is important in the control of people potentially at risk of TB disease, such as people remaining in close contact with $\mathrm{BK}(+)$ tb patient and for patients evaluated for biological treatment. The paper presents the value of IGRA in three selected clinical situations: in two cases of latent tuberculosis infection and in one case of active tuberculosis.

Key words: latent tuberculosis infection, IGRA-Interferon-Gamma Release Assay, tuberculin skin test, tuberculosis

Pneumonol. Alergol. Pol. 2014; 81: 39-45

\section{Streszczenie}

Przez wiele lat podstawowym testem identyfikującym latentne (utajone) zakażenie prątkami gruźlicy (LTBI) była próba tuberkulinowa, posiadająca pewne ograniczenia, które wynikają przede wszystkim z niskiej czułości i specyficzności. Obecnie stosuje się testy IGRA z krwi obwodowej, umożliwiające szybką diagnostykę LTBI poprzez pomiar interferonu gamma (IFN- $\gamma$ ) wydzielanego przez limfocyty T pobudzone swoistymi dla Mycobacterium tuberculosis antygenami. Wykrywanie LTBI ma istotne znaczenie w kontroli osób potencjalnie zagrożonych zachorowaniem na gruźlicę, na przykład przebywających w bliskim kontakcie z chorymi prątkującymi oraz dla pacjentów kwalifikowanych do leczenia lekami biologicznymi. W pracy przedstawiono 3 wybrane sytuacje kliniczne, w których zastosowano testy IGRA. W dwóch przypadkach rozpoznano ostatecznie utajone zakażenie prątkami gruźlicy, a w jednym aktywną gruźlicę.

Słowa kluczowe: latentne zakażenie prątkami gruźlicy, testy IGRA, próba tuberkulinowa, gruźlica

Pneumonol. Alergol. Pol. 2014; 81: 39-45

Adres do korespondencji: mgr Dagmara Borkowska, Zakład Mikrobiologii IGiChP, ul. Płocka 26, 01-138 Warszawa

tel./faks: 2243121 82, e-mail: d.borkowska@igichp.edu.pl

10.5603/PiAP.2014.0007

Praca wpłyneła do Redakcji: 8.02.2013 r.

Copyright (C) 2014 PTChP

ISSN 0867-7077 


\section{Wstęp}

Zakażenie prątkami gruźlicy następuje najczęściej na drodze inhalacyjnej, a czynnikiem etiologicznym są prątki należące do grupy Mycobacterium tuberculosis complex [1]. Zakażenie prątkami nie zawsze prowadzi do zachorowania, ponieważ o losie bakterii w organizmie decydują intensywność ekspozycji, stopień zjadliwości prątków oraz osobnicza oporność lub wrażliwość na zakażenie wynikająca z nieswoistej aktywacji makrofagów [2].

W pierwszym okresie zakażenia prątki wychwytywane są przez makrofagi pęcherzykowe, ulegają zniszczeniu lub przeżywają, powoli namnażając się w ich wnętrzu. Może to spowodować rozpad komórek i wydalenie bakterii na zewnątrz z pochłonięciem ich przez monocyty krwi obwodowej [2, 3]. Przebieg pierwszej fazy zakażenia gruźliczego zależy od sprawności mechanizmów nieswoistej odporności wrodzonej. W monocytach, które nie są komórkami aktywowanymi, prątki gruźlicy mogą namnażać się w ich wnętrzu. Rozpoczyna się drugi okres zakażenia nazywany logarytmicznym wzrostem prątków, który trwa około 2-3 tygodni. W tym okresie zaczynają się budzić reakcje obronne ustroju gospodarza. Rozwija się swoista nabyta odporność komórkowa. Dochodzi do aktywowania makrofagów niszczących komórki prątków w reakcji mediowanej przez limfocyty CD4, Th1 i wydzielanego przez nie interferonu gamma (IFN- $\gamma$ ). Komórki NK (natural killers), limfocyty gammadelta i limfocyty CD8 biorą udział w niszczeniu własnych komórek i tkanek w celu zahamowania wzrostu prątków. Powstaje martwica serowata, wokół której gromadzą się komórki nabłonkowate i limfocyty, tworząc gruzełek gruźliczy otoczony tkanką łączną wysyconą z czasem solami wapnia. Odgraniczenie prątków od zdrowej tkanki, redukcja dostępu tlenu i czynników odżywczych hamuje rozwój prątków, spowalnia ich metabolizm. Prątki wchodzą wówczas w stan uśpienia (latencji). Gruzełki gruźlicze mogą przetrwać w ustroju przez wiele lat bez objawów choroby [2-5]. U 5-10\% osób, które przebyły zakażenie Mycobacterium tuberculosis, może dojść do reaktywacji zakażenia i rozwoju gruźlicy $[2,3]$.

$\mathrm{W}$ diagnostyce utajonego zakażenia prątkami gruźlicy LTBI (latent tuberculosis infection) ważne są: kompleksowy wywiad lekarski w celu ustalenia czynników ryzyka zakażenia, badanie przedmiotowe i radiologiczne klatki piersiowej oraz ocena odczynu tuberkulinowego i/lub testu IGRA (interferon-gamma release assay). Zasadniczym czynnikiem ryzyka LTBI jest bliski kontakt z chorym prątkującym. Utajone zakażenie prątkami gruźlicy stwierdza się także częściej u osób pochodzących z regionów o wysokiej zapadalności na gruźlicę, takich jak Afryka, Azja, Wschodnia Europa, Ameryka Południowa, Rosja [6, 7].

Pewne rozpoznanie aktywnej gruźlicy można ustalić jedynie po wykryciu obecności prątków $\mathrm{w}$ badaniach bakteriologicznych (posiew na pożywkach płynnych i stałych, badanie molekularne $\mathrm{u}$ chorego z dodatnim badaniem bakterioskopowym, ziarnina gruźlicza i dodatnie badanie bakterioskopowe). „Złotym standardem” nadal pozostaje wyhodowanie prątków [8-12].

Do niedawna głównym narzędziem diagnostycznym w wykrywaniu utajonego zakażenia prątkiem gruźlicy była próba tuberkulinowa TST (tuberculin skin test), której wyniki mogą być obarczone błędem [13]. Niska specyficzność najstarszego z testów diagnostycznych wynika ze składu tuberkuliny, która jest mieszaniną około 200 niespecyficznych białek wspólnych dla prątków chorobotwórczych, szczepu szczepionkowego BCG (Bacillus Calmette-Guerin) i mykobakterii z grupy MOTT (mycobacteria other than tuberculosis) [8]. Wyniki dodatnie świadczą jedynie o wcześniejszym kontakcie z prątkami, nie rozstrzygając, czy jest to $M$. tuberculosis, prątki atypowe czy BCG $[13,14]$. Testy IGRA wykonane z krwi obwodowej mają na celu wykrywanie utajonego zakażenia prątkami gruźlicy [13, 14]. Mają one wysoką wartość diagnostyczną, ponieważ są oparte na specyficznych antygenach prątka gruźlicy ESAT-6 (early secretory antigenic target) i CFP-10 (culture filtrate protein) kodowanych w regionie RD1, nieobecnych u Mycobacterium bovis BCG i u prątków środowiskowych z wyjątkiem $M$. kansasi, M. szulgai, M. marinum. Dzięki temu możliwe jest zmniejszenie liczby wyników fałszywie interpretowanych jako dodatnie na podstawie TST. Dotyczy to populacji szczepionych BCG lub zakażonych prątkami niegruźliczymi z wyjątkiem wyżej wymienionych szczepów. Dlatego IGRA charakteryzuje wyższa swoistość w stosunku do standardowej próby tuberkulinowej.

Interpretacja wyników IGRA jest obiektywna i polega na pomiarze stężenia IFN- $\gamma$ wydzielanego przez limfocyty $\mathrm{T}$ w odpowiedzi na swoiste antygeny Mycobacterium tuberculosis za pomocą techniki ELISA (enzyme-linked immunosorbent assay) lub na zliczaniu limfocytów T wydzielających cytokinę przy użyciu metody ELISpot [7, 13-21].

Celem niniejszej pracy było przedstawienie zastosowania testów IGRA w diagnostyce zakażenia prątkiem gruźlicy w różnych sytuacjach klinicznych. 


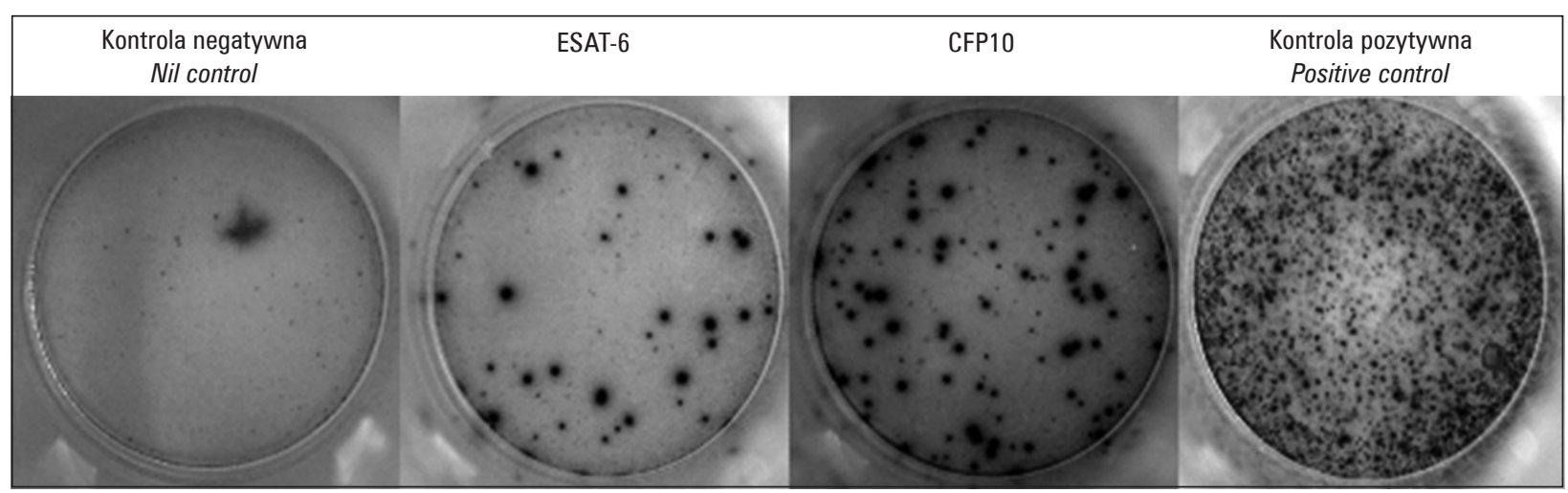

Rycina 1. Pozytywny wynik testu T-SPOT.TB potwierdzający utajone zakażenie prątkami gruźlicy u 13-letniego chłopca

Figure 1. Positive T-SPOT.TB result confirm latent tuberculosis infection in a 13-year-old boy

\section{Opisy przypadków}

\section{Przypadek 1}

Trzynastoletni chłopiec pochodzący z Czeczeni, przebywający w ośrodku dla uchodźców, został przyjęty na jeden z oddziałów pediatrycznych $\mathrm{w}$ Warszawie z powodu podejrzenia zakażenia prątkami gruźlicy w wyniku ekspozycji rodzinnej. Rodzice chłopca, młodzi uchodźcy z Czeczeni, chorowali w tym czasie na gruźlicę. Diagnostyka mikrobiologiczna u rodziców została wykonana w Laboratorium Prątka Gruźlicy w IGiChP w Warszawie. Z płynu z otrzewnej od ojca i plwociny od matki wyizolowano prątki gruźlicy typu Beijing o oporności na izoniazyd i streptomycynę. Chłopiec miał codzienny kontakt z chorującymi dorosłymi. W chwili badania nie obserwowano objawów klinicznych wskazujących na gruźlicę, nie stwierdzono gorączki, ubytku masy ciała. W badaniu przedmiotowym nie stwierdzono odchyleń od stanu prawidłowego. W badaniu radiologicznym (RTG) klatki piersiowej nie uwidoczniono zmian patologicznych. Wykonano serię badań mikrobiologicznych z 7 materiałów klinicznych ( $3 \times$ popłuczyny żołądkowe, $2 \times$ płyn z płukania oskrzeli, $2 \times$ plwocina) pobranych od pacjenta. Wyniki bakterioskopii, badań genetycznych były ujemne, nie uzyskano wzrostu prątków w hodowli.

W celu wykrycia utajonego zakażenia prątkami gruźlicy równoczasowo wykonano próbę tuberkulinową i test IGRA (T-SPOT.TB) z krwi obwodowej. Odczyn tuberkulinowy wynosił $20 \mathrm{~mm}$, a testem T-SPOT.TB wykryto limfocyty $\mathrm{T}$ pobudzone przez specyficzne antygeny prątka gruźlicy w postaci ciemnogranatowych plam (ryc. 1). Rozpoznano utajone zakażenie prątkami gruźlicy. Zastosowano profilaktyczne leczenie przeciwprątkowe.

\section{Przypadek 2}

Chora (29 lat) nigdy niepaląca tytoniu, ekonomistka, została przyjęta na oddział Chorób Płuc IGiChP w Warszawie z podejrzeniem choroby śródmiąższowej ze zmianami torbielowatymi. Od 4 lat utrzymywał się kaszel z odkrztuszaniem ropnej plwociny. W ciągu ostatniego roku schudła $5 \mathrm{~kg}$ i pojawiły się bóle w klatce piersiowej. Od ponad 15 lat leczona była z powodu alergicznego zapalenia błony śluzowej nosa i spojówek gałkowych, z obecnością uczulenia na pyłki traw, brzozy i topoli. W badaniach dodatkowych stwierdzono leukocytozę $9,56 \times 10^{9} / 1$, neutrofilię 7,69 $\times 10^{9} / \mathrm{l}$, obniżone stężenie hemoglobiny 10,82 g/l przy prawidłowej liczbie krwinek czerwonych 4,52 $\times 10^{12} /$ l. Markery zapalne były podwyższone: odczyn opadania krwinek po 1 godzinie wynosił $58 \mathrm{~mm}$, a białko CRP (C-reactive protein) 42,4 mg/l. Stwierdzono prawidłowe stężenie białek krwi (całkowite białko 7,6 g/l, albuminy 46,3\%, $\alpha_{1}$-globulina $2,3 \% \quad \alpha_{2}$-globulina $14,8 \%, \beta$-globulina $15,8 \%$, $\gamma$-globulina $20,8 \%$ ). W badaniu radiologicznym klatki piersiowej uwidoczniono liczne zmiany guzkowe w górnych i środkowych polach płucnych z obecnością przejaśnień. Zmiany te były znacznie lepiej widoczne w badaniu tomokomputerowym klatki piersiowej, a obserwowane przejaśnienia wynikały z obecności znacznych rozstrzeni oskrzeli w obrębie płata środkowego i języczka. Bronchoskopowo stwierdzono drzewo oskrzelowe o prawidłowym kształcie i przebiegu, z obecnością ropnej wydzieliny. W trzykrotnych badaniach plwociny i w wydzielinie oskrzelowej wykryto w badaniu bezpośrednim prątki (ryc. 2). Wynik badania genetycznego potwierdził, że są to prątki gruźlicy. Po 3 tygodniach ze wszystkich pobranych materiałów wyhodowano prątki Mycobacterium tuberculosis complex wrażliwe 

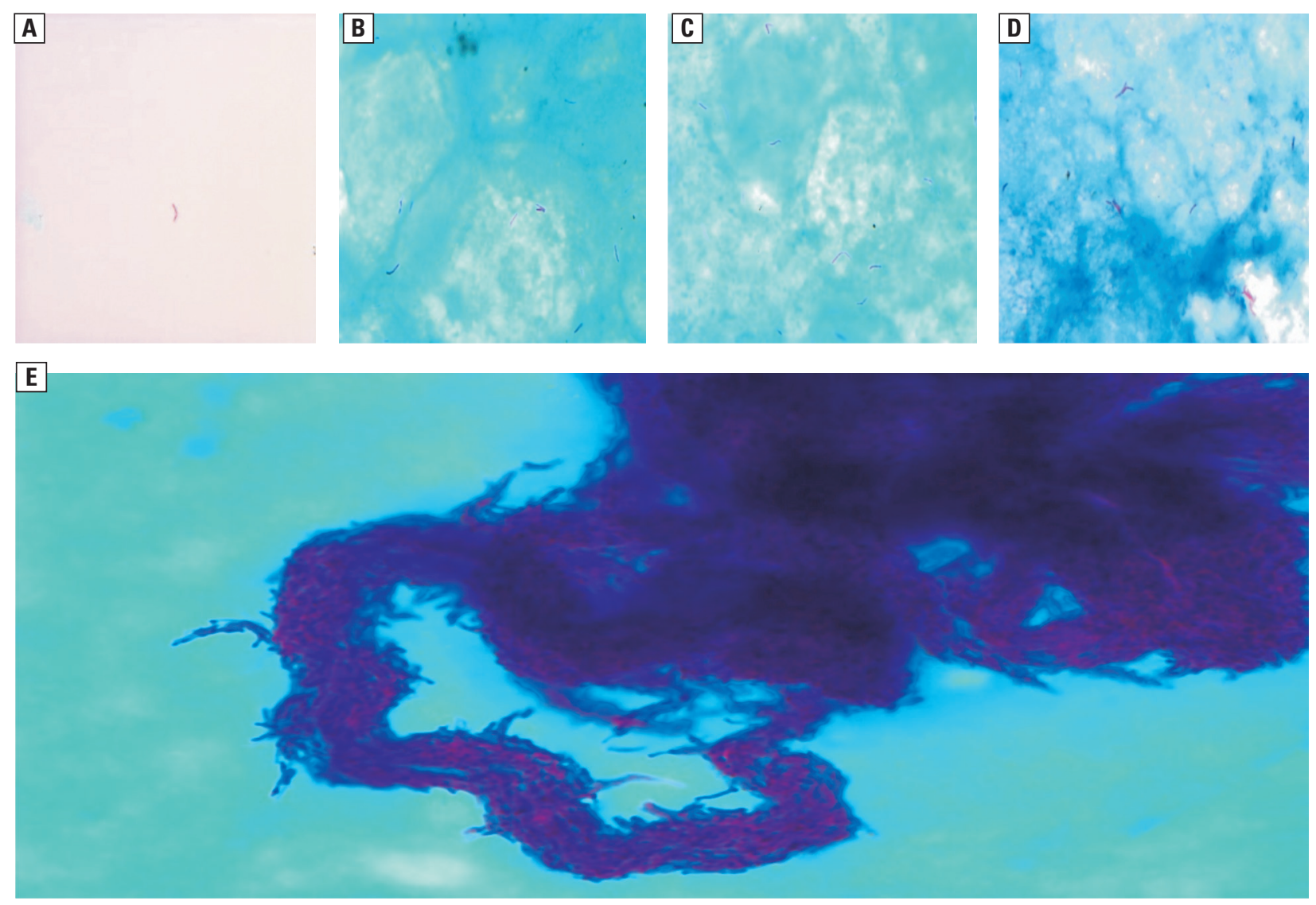

Rycina 2. Preparaty barwione metodą Ziehla-Neelsena z materiałów klinicznych pobranych od 29-letniej kobiety chorej na gruźlicę: wydzielina oskrzelowa - stwierdzono obecność pojedynczych prątków kwasoodpornych (A); plwociny z 3 kolejnych dni — stwierdzono obecność prątków kwasoodpornych $(+++)(\mathrm{B}-\mathrm{D})$; hodowla prątków (E)

Figure 2. Mycobacterium tuberculosis complex stained by using the Ziehl-Neelsen method, in clinical materials from the 29-year-old woman with tuberculosis: bronchial washing — revealed the presence of a single mycobacteria (A); Sputum Acid Fast Bacilli $(+++)(B-D)$; mycobacterial culture (E)

\section{Tabela 1. Wyniki badań mikrobiologicznych w kierunku gruźlicy u 29-letniej kobiety chorej na gruźlicę}

Table 1. The results of microbiological tests in 29 year old woman with tuberculosis

\begin{tabular}{|c|c|c|c|c|}
\hline & $\begin{array}{c}\text { Wydzielina oskrzelowa } \\
\text { Bronchial secretions }\end{array}$ & $\begin{array}{l}\text { Plwocina } \\
\text { Sputum }\end{array}$ & $\begin{array}{l}\text { Plwocina } \\
\text { Sputum }\end{array}$ & $\begin{array}{l}\text { Plwocina } \\
\text { Sputum }\end{array}$ \\
\hline AFB & Poj./Single & +++ & +++ & +++ \\
\hline $\begin{array}{l}\text { Posiew } \\
\text { Culture }\end{array}$ & $\begin{array}{c}\text { M. tbc - system auto- } \\
\text { matyczny } \\
\text { Automated system }\end{array}$ & $\begin{array}{l}\text { M. tbc - wzrost po } \\
3 \text { tyg. pożywka LJ } \\
\text { Growth after } 3 \\
\text { weeks - LJ medium }\end{array}$ & $\begin{array}{l}\text { M. tbc — wzrost po } \\
3 \text { tyg. pożywka LJ } \\
\text { Growth after } 3 \text { weeks } \\
\text { - LJ medium }\end{array}$ & $\begin{array}{c}\text { M. tbc - wzrost po } \\
3 \text { tyg. pożywka LJ } \\
\text { Growth after } 3 \text { weeks } \\
\text { - LJ medium }\end{array}$ \\
\hline $\begin{array}{l}\text { Test niacynowy } \\
\text { Niacin test }\end{array}$ & & + & & \\
\hline $\begin{array}{l}\text { Badanie genetyczne } \\
\text { Nucleic acid } \\
\text { amplification test }\end{array}$ & & + & & \\
\hline
\end{tabular}

na wszystkie leki przeciwprątkowe (tab. 1). Na 2 tygodnie przed przyjęciem do IGiChP chora miała wykonany test tuberkulinowy, który był ujem- ny. W IGiChP wykonano test T-SPOT.TB, który również był negatywny (ryc. 3). Chora otrzymała leczenie przeciwprątkowe, nastąpiła poprawa. 


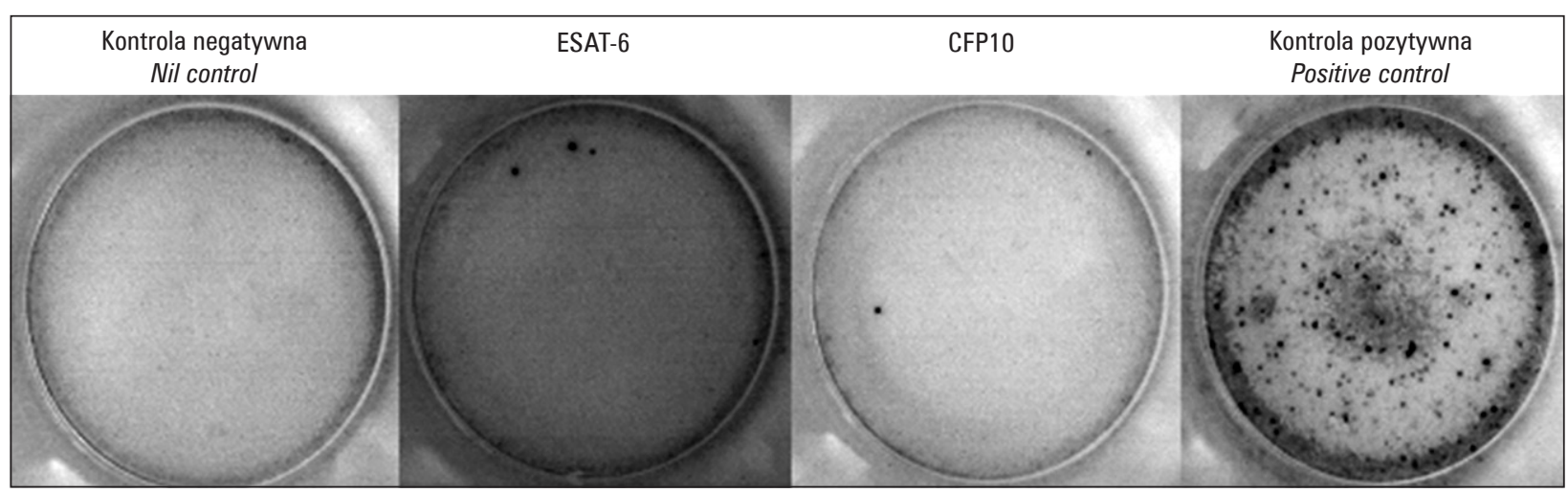

Rycina 3. Negatywny wynik testu T-SPOT.TB w kierunku utajonego zakażenia prątkami gruźlicy u 29-letniej kobiety chorej na gruźlicę

Figure 3. Negative T-SPOT.TB result in a 29-year-old woman suffering from tuberculosis

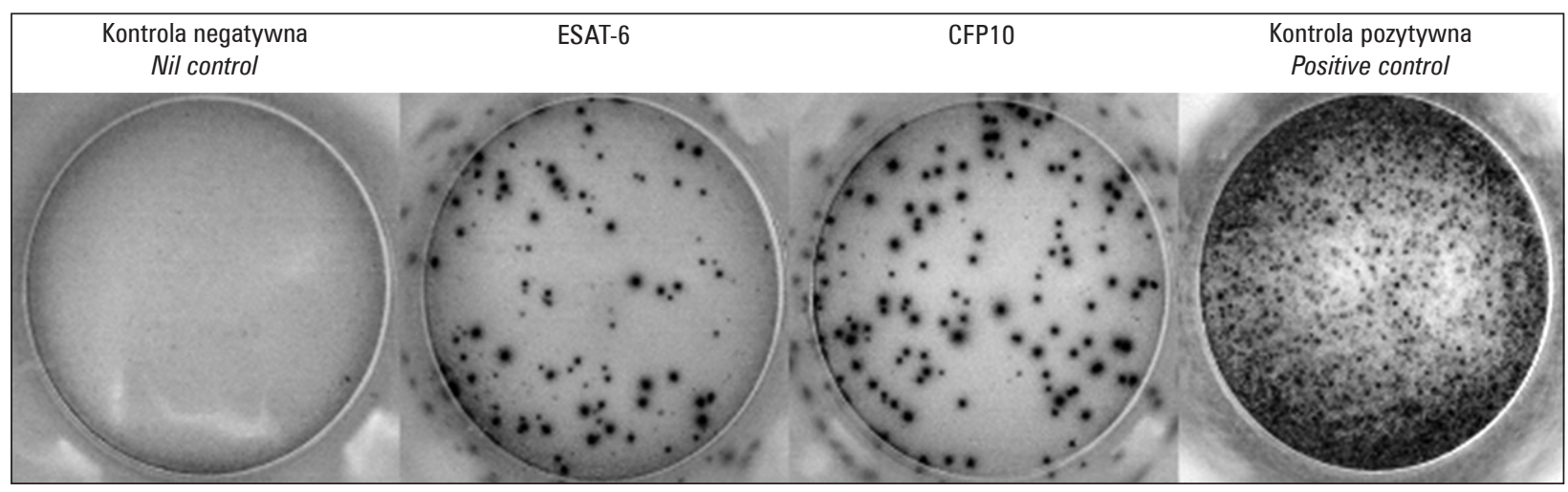

Rycina 4. Pozytywny wynik testu T-SPOT.TB potwierdzający utajone zakażenie prątkami gruźlicy u 67-letniego mężczyzny chorującego na zesztywniające zapalenie stawów kręgosłupa

Figure 4. Positive T-SPOT.TB result confirm latent tuberculosis infection in a 67 year-old man suffering from ankylosing spondylitis

\section{Przypadek 3}

Pacjent (67 lat), palący papierosy, chorujący od wielu lat na zesztywniające zapalenie stawów kręgosłupa, po nieskutecznym leczeniu niesteroidowymi lekami przeciwzapalnymi został wstępnie zakwalifikowany przez lekarza reumatologa do leczenia biologicznego. Warunkiem wdrożenia leczenia anty-TNF- $\alpha$ (tumor necrosis factor alfa) było wykluczenie aktywnej gruźlicy i latentnego zakażenia prątkami gruźlicy. W związku z tym chory zgłosił się na konsultację pulmonologiczną do Instytutu Gruźlicy i Chorób Płuc. Nie zgłaszał dolegliwości ze strony układu oddechowego. Nie stwierdzono odchyleń od stanu prawidłowego $\mathrm{w}$ badaniu przedmiotowym płuc. $\mathrm{W}$ badaniu radiologicznym klatki piersiowej widoczny był zwapniały zespół pierwotny, nie stwierdzono natomiast cech przemawiających za aktywnym procesem gruźliczym. Wykonano próbę tuberkulinową i oba testy IGRA (T-SPOT.TB [ryc. 4] i Quantiferon TB.GOLD). Odczyn tuberkulinowy wynosił $0 \mathrm{~mm}$, natomiast wyniki testów IGRA były dodatnie. Z uwagi na obecność zespołu pierwotnego w obrazie RTG klp i planowane leczenie anty-TNF- $\alpha$, chory został zakwalifikowany do profilaktycznego leczenia przeciwprątkowego rifampicyną i izoniazydem. Obecność utajonego zakażenia została potwierdzona dodatkowo testami IGRA.

\section{Omówienie}

Testy IGRA służą do wykrywania LTBI i są wykorzystywane najczęściej w badaniu osób, które miały kontakt z chorymi prątkującymi, a także u chorych kwalifikowanych do leczenia biologicznego inhibitorami TNF- $\alpha[7,12,13]$. Rekomendacje dotyczące stosowania testów IGRA i próby tuberkulinowej TST do diagnostyki LTBI różnią się w poszczególnych krajach. Istotną kwestią, która pozostaje do wyjaśnienia, jest pytanie, czy testy IGRA należy stosować zamiast, czy w połączeniu z próbą tuberkulinową. W różnych krajach proponuje się odmienne wytyczne $[6,7,21,22]$. 
W Stanach Zjednoczonych Centers of Disease Control zaleciło używanie testów IGRA zamiast TST w każdej sytuacji klinicznej, podobnie jak w Niemczech i Szwajcarii. W Hiszpanii, Wielkiej Brytanii, Kanadzie i we Włoszech preferuje się strategię diagnostyki LTBI dwuetapowo: wstępne badanie TST, po nim dopiero IGRA, w przypadkach gdy TST jest dodatnie. We Francji TST i IGRA stosuje się natomiast wymiennie [7, 21, 22]. Australijskie wytyczne nie oferują żadnego konkretnego zalecenia do stosowania testów IGRA, niektórzy proponują wykonanie testu IGRA po negatywnym wyniku próby tuberkulinowej, inni zastępują TST testami IGRA [6].

Brakuje również szczegółowych wytycznych dla osób w immunosupresji (bez uwzględnienia zakażonych HIV). Kanadyjczycy zalecają korzystanie z TST z/bez dodatkowego testu IGRA, a Wielka Brytania i Szwajcaria — zastąpienie TST testami IGRA [6].

W kontekście zlecania badań w kierunku LTBI ważne jest ustalenie wpływu wcześniejszego podania tuberkuliny na wyniki testów IGRA.

Van Zyl-Smit i wsp. pobierali krew do testów QFT-GIT i T-SPOT.TB dzień przed wykonaniem TST, w tym samym dniu co TST i 84 dni po TST. Zaobserwowali, że do 3 dni po wykonaniu TST stężenie IFN- $\gamma$ nie wzrastało, natomiast w 7 . dniu wzmocnienie reakcji immunologicznej było znaczne i zmieniało wynik wcześniejszego testu IGRA z ujemnego na dodatni. W przypadku, gdy najpierw wykonano próbę tuberkulinową, a po stwierdzeniu dodatniego odczynu tuberkulinowego zlecono test IGRA, krew należy pobrać najpóźniej 3 dni od śródskórnego podania tuberkuliny [23]. Jeżeli ten czas został przekroczony, to wynik testu IGRA jest wiarygodny dopiero po upływie 6 miesięcy [24]. Kanadyjskie wytyczne zalecają pobranie krwi na badanie testami IGRA do 1 dnia po założeniu TST [25]. Taka rygorystyczna kolejność wykonania testów wynika z faktu, że tuberkulina zawiera w swym składzie specyficzne antygeny Mycobacterium tuberculosis ESAT-6 i CFP 10, które mogą wpływać na wynik testu IGRA, o ile zostanie on wykonany w czasie dłuższym niż rekomendowany [7, 23-25].

Przedstawione tu przypadki kliniczne potwierdzają dane z piśmiennictwa, że testy IGRA $\mathrm{z}$ krwi są przydatne przede wszystkim do diagnozowania utajonego zakażenia prątkami gruźlicy, a nie aktywnej choroby. W czynnej gruźlicy, szczególnie u chorych w immunosupresji, zarówno TST, jak IGRA mogą być ujemne. Problem ten ilustruje przypadek 2 .
Przypadek pierwszy dotyczył zakażenia prątkami gruźlicy u 13-letniego chłopca, u którego źródłem zakażenia byli chorzy rodzice. Dodatnie wyniki testu IGRA, zgodne z wynikiem TST, świadczyły o tym, że chłopiec był zakażony prątkami gruźlicy. Nieobecność objawów choroby i ujemne wyniki badań mikrobiologicznych pozwalały na wykluczenie w tym przypadku gruźlicy aktywnej.

Przypadek trzeci dotyczył chorego na zesztywniające zapalenie stawów kręgosłupa, któremu zlecono wykonanie badań przed planowanym leczeniem biologicznym anty-TNF- $\alpha$. Badania miały na celu diagnostykę w kierunku LTBI, ponieważ wśród chorych poddanych tego typu leczeniu ryzyko zachorowania na gruźlice jest wielokrotnie wyższe niż w ogólnej populacji [26]. U chorego stwierdzono $\mathrm{w}$ obrazie radiologicznym klatki piersiowej zwapniały zespół pierwotny. Świadczyło to o przebytej gruźlicy i wskazywało na konieczność zastosowania profilaktycznego leczenia przeciwprątkowego. W tej sytuacji klinicznej, która jednoznacznie przemawiała za zakażeniem prątkiem gruźlicy w przeszłości, wynik próby tuberkulinowej był ujemny, a wynik testów IGRA - dodatni. Może to świadczyć o wyższej wartości diagnostycznej testów IGRA w wykrywaniu odległego zakażenia M. tuberculosis. Dane z literatury przemawiają również za większą czułością testów IGRA niż TST w rozpoznawaniu zakażenia prątkami u chorych znajdujących się w immunosupresji [26-28].

\section{Podsumowanie}

1. Analiza przedstawionych przypadków wykazała, że testy IGRA z krwi obwodowej nie są przydatne do wykrywania czynnej postaci gruźlicy u dorosłych. Testy te nie mogą zastąpić klasycznej diagnostyki mikrobiologicznej: bakterioskopii, posiewu, badań molekularnych.

2. Nie można rozpoznać gruźlicy na podstawie dodatniego wyniku testu IGRA, natomiast ujemny wynik testu IGRA nie wyklucza czynnej postaci gruźlicy. Do prawidłowego rozpoznania zachorowania na gruźlicę konieczne jest przeprowadzenie wywiadu lekarskiego, badania przedmiotowego, zdjęcia radiologicznego i badań mikrobiologicznych.

3. Testy IGRA nie są przydatne do różnicowania aktywnej gruźlicy i utajonego zakażenia prątkami gruźlicy.

4. Testy IGRA i TST powinny być używane jako pomoc w diagnozowaniu utajonego zakażenia prątkami gruźlicy. Badania mogą 
być wykorzystane do celów nadzoru lub identyfikacji osób z LTBI, które mogą skorzystać z leczenia profilaktycznego. Dotyczy to zakażonych, którzy mają zwiększone ryzyko rozwoju aktywnej postaci choroby.

\section{Konflikt interesów}

Autorzy deklarują brak konfliktu interesów.

\section{Piśmiennictwo:}

1. Ahmad S. Pathogenesis, immunology, and diagnosis of latent Mycobacterium tuberculosis infection. Clin. Dev. Immunol. 2011; 2011: 814943.

2. Gajewski P. Interna Szczeklika. Podręcznik chorób wewnętrznych 2013. Wydawnictwo Medycyna Praktyczna, Kraków 2013; 717-731.

3. Rudnicka W. Molekularne aspekty odporności na gruźlicę. Post. Mikrobiol. 2004; 43: 107-127.

4. Jakóbisiak M. Immunologia. Wydawnictwo Naukowe PWN, Warszawa 1998; 153-168.

5. Saunders B.M., Britton W.J. Life and death in the granuloma: immunopathology of tuberculosis. Immunol. Cell Biol. 2007; 85: 103-111.

6. Rogerson T.E., Chen S., Kok J. i wsp. Tests for latent tuberculosis in people with ESRD: a systematic review. Am. J. Kidney Dis. 2012; 61: 33-43.

7. Mazurek G.H., Jereb J., Vernon A. i wsp. Updated guidelines for using interferon gamma release assays to detect Mycobacterium tuberculosis infection. MMWR 2010; 59: 1-25.

8. Augustynowicz-Kopeć E., Demkow U., GrzelewskaRzymowska I. i wsp. Zalecenia Polskiego Towarzystwa Chorób Płuc dotyczące rozpoznania, leczenia i zapobiegania gruźlicy u dorosłych i dzieci. Pneumonol. Alergol. Pol. 2013; 81: 323-379.

9. Augustynowicz-Kopeć E., Zwolska Z. Postępy w diagnostyce i epidemiologii molekularnej Mycobacterium tuberculosis. Post. Mikrobiol. 2010; 49: 151-156.

10. Ling D.I., Zwerling A.A., Steingart K.R., Pai M. Immune-based diagnostics for TB in children: what is the evidence? Paediatr. Respir. Rev. 2011; 12: 9-15.

11. Sester M., Sotgiu G., Lange C. i wsp. Interferon- $\gamma$ release assays for the diagnosis of active tuberculosis: A systematic review and meta-analysis. Eur. Respir. J. 2011; 37: 100-111.

12. Diel R., Goletti D., Ferrara G. Interferon $-\gamma$ release assays for the diagnosis of latent $M$. tuberculosis infection: A systematic review and meta-analysis. Eur. Respir. J. 2011; 37: 88-99.

13. Borkowska D., Zwolska Z., Broniarek-Samson B. i wsp. Porównanie testów IGRA i próby tuberkulinowej w rozpoznaniu utajonego zakażenia prątkiem gruźlicy. Post. Nauk Med. 2011; 10: 836-841.
14. Lalvani A. Diagnosing tuberculosis infection in the $21^{\text {st }}$ century. New tools to tackle an old enemy. Chest 2007; 131: 1898-1906.

15. Santin M., Casas S., Saumoy M. i wsp. Detection of latent tuberculosis by the tuberculin skin test and a whole-blood interferon-\% release assay, and the development of active tuberculosis in HIV-seropositive persons. Diagn. Microbiol. Infect. Dis. 2011; 69: 59-65.

16. Pai M., Riley L.W., Colford Jr J.M. Interferon- $\gamma$ assay in the immunodiagnosis of tuberculosis: a systematic review. Lancet Infect. Dis. 2004; 4: 761-776.

17. Lalvani A. Counting antigen-specific T cells: a new approach for monitoring response to tuberculosis treatment? CID 2004; 38: 757-759.

18. van Pinxteren L.A.H., Ravn R., Agger E.M., Pollock J., Andersen P. Diagnosis of tuberculosis based on the two specific antigens ESAT-6 and CFP 10. Clin. Diagn. Lab. Immunol. 2000; 7: 155-160.

19. Lee J.Y., Choi H.J., Park I.N. i wsp. Comparison of two commercial interferon- $\gamma$ assays for diagnosing Mycobacterium tuberculosis infection. Eur. Respir. J. 2006; 28: 24-30.

20. Kim H.J., Yoon H.I., Park K.U., Lee C.T., Lee J.H. The impact of previous tuberculosis history on T-SPOT.TB interferon-gamma release assay results. Int. J. Tuberc. Lung Dis. 2011; 15: 510-516.

21. Sauzullo I, Massetti A.P., Mengoni F. i wsp. Influence of previous tuberculin skin test on serial IFN-- release assays. Tuberculosis 2011; 91: 322-326.

22. Vassilopoulos D., Tsikrika S., Hatzara C. i wsp. Comparison of two gamma interferon release assays and tuberculin. Skin testing for tuberculosis screening in a cohort of patients with rheumatic diseases starting anti-tumor necrosis factor therapy. CVI 2011; 18: 2102-2108.

23. van Zyl-Smit R.N., Pai M., Peprah K. i wsp. Within-subject variability and boosting of T-cell interferon-gamma responses after tuberculin skin testing. Am. J. Respir. Crit. Care Med. 2009; 180: 49-58.

24. Demkow U. Komentarz do pracy K. Kruczak i E. Niżankowskiej-Mogilnickiej: „Nowe możliwości diagnostyki utajonego zakażenia prątkiem gruźlicy”. Pneumonol. Alergol. Pol. 2008; 76: 468-471.

25. Miranda C., Tomford J.W., Gordons M. Interferon-gamma-release assays: Better than tuberculin skin testing? CCJM 2010; 77: 606-611.

26. Kim J.H., Cho S.K., Han M. i wsp. Factors Influencing Discrepancies Between the QuantiFERON-TB Gold in Tube Test and the Tuberculin Skin Test in Korean Patients with Rheumatic Diseases. Semin. Arthritis Rheum. 2012; 42: 424-432.

27. Korzeniewska-Koseła M. Zalecenia postępowania diagnostycznego i terapeutycznego. Zapobieganie gruźlicy u leczonych antagonistami TNF. Reumatologia 2010; 48: 4-13.

28. Girlanda S., Mantegani P., Baldissera E. i wsp. ELISPOT-INF- $\gamma$ assay instead of tuberculin skin test for detecting latent $\mathrm{My}$ cobacterium tuberculosis infection in rheumatic patients candidate to anti-TNF- $\alpha$ treatment. Clin. Rheumatol. 2010; 29: 1135-1141. 